\title{
Environmental safety in the countries bordering Kazakhstan in the context of sustainable development
}

\author{
Zeinegul Yessymkhanova ${ }^{1}, \quad$ Shakizada Niyazbekova ${ }^{2, *}$, Zhanar Dauletkhanova ${ }^{3}$, \\ Nurdin Dzholdoshev ${ }^{4}$, and Tamara Dzholdosheva ${ }^{5}$ \\ ${ }^{1}$ Turan-Astana University, the Department of Finance, 010000, 29, Ykylas Dukenuly street, Nur- \\ Sultan, Kazahkstan \\ ${ }^{2}$ Moscow Witte University, Department finance and economy, 119454, 2-I Kozhukhovski p., 12, bd. \\ 1, Moscow, Russia \\ ${ }^{3}$ The Eurasian Humanities Institute, Department of Economics and Mathematical Disciplines, \\ 010009, 4, Zhumabaev bld., Nur-Sultan, Kazakhstan \\ ${ }^{4}$ International Academy of Management, Law, Finance and Business, 720001, 6a str. Belorusskaya, \\ Bishkek, Kyrgyzstan \\ ${ }^{5}$ M. Ryskulbekov Kyrgyz economic University, 720001, 58, Togolok Moldo str., Bishkek, \\ Kyrgyzstan
}

\begin{abstract}
Current situation in the environmental sector for the EAEU countries it is one of the most burning topics. One of the priority areas of the country's sustainable development policy The Eurasian economic Union recognizes ensuring the welfare of the population living in the Eurasian space and introducing environmental technologies, creating environmentally friendly industries, and much more. Important changes have taken place in the environmental safety sector, and positive dynamics are beginning to be determined not only by intentions, but also by real actions aimed at improving the quality of the environment and health. In the context of globalization, the nature of the market-plan relationship in environmental management is changing dramatically. On the one hand, the influence of market forces and competition that stimulate the development and implementation of environmental policies by each individual state is increasing. On the other hand, the impact of international economic institutions on national relations is increasing, resulting in the creation of a system of supranational environmental management. Joint solution of issues related to prevention of negative impact on the environment is possible only through: contractual actions, investment policies, and planned activities aimed at maintaining environmental balance. Kazakhstan, being a full member of the EAEU actively participates in the formation of a regulatory framework aimed at reducing industrial risks, identifying the scale of anthropogenic pollution and implementing environmental monitoring.
\end{abstract}

${ }^{*}$ Corresponding author: shakizada.niyazbekova@gmail.com 


\section{Introduction}

In the countries of the Eurasian economic Union (hereinafter EEU) there are serious environmental problems. So, on the territory of Russia has 500 million cubic meters of nuclear waste. According to the Ministry of natural resources and environment, there is a high degree of pollution in 194 territories in the country and 2.3 million tons of toxic waste are accumulated in total. Landfills cover 1 million hectares, and the total amount of waste exceeded 3.5 billion tons. $56 \%$ of the urban Russian population lives in polluted areas; 58.2 million people in 142 Russian cities breathe poisoned air. Environmental degradation affects health and on the state of the genetic Fund of Russians. More than $20 \%$ of the territory Russia is an ecological disaster area. More than 70 million Russians breathe air saturated with substances dangerous to health, 5 times or more exceeding the maximum permissible standards. According to some experts, economic losses from damage caused to the environment by negligent attitude to the environment account for half of Russia's national income [1-3].

Ecology Kazakhstan is also extremely dysfunctional. There is a large shortage of water resources in the country. This is due to an environmental disaster The Aral Sea, of which a fourth part by area and a tenth by volume remained, which led to salinization and soil erosion. Environmental problems exist with lake Balkhash. Intensive development of the Caspian Sea shelf resources the sea has led to the depletion of the country's water resources. An environmental disaster zone is Semipalatinsk region, where the military space test site was located and where atomic weapons were tested for 40 years, which results in radioactive, bacteriological and chemical contamination of land resources over an area of 300 square kilometers. This region has an increased rate of cancer and other diseases. The country has accumulated about 43 billion tons of waste from production and consumption, with only a small amount of waste generated in the country. $5 \%$ of solid household waste is disposed of or incinerated, the rest is sent to landfill [2]. in 15 large cities of Kazakhstan, the permissible level of air pollution has been exceeded. The main volume of anthropogenic greenhouse emissions is accounted for by the energy sector, which in the country it is mainly focused on coal, which produces the highest $\mathrm{CO} 2$ emissions [3]. Climate change in the country is proceeding at a faster pace than the global average [4].

In Belarus, the most acute environmental problem is radioactive contamination due to the Chernobyl accident, which polluted about $22 \%$ of the territory where people live. 2.2 million people [5]. The problem is air pollution, surface and underground waters, pollution and soil degradation. The country is located in the center of Europe, and, on the one hand, occupies an advantageous transport and geographical position, but, on the other hand, its disadvantage is the presence of cross-border transport of pollutants from Europe; the impact of the consequences of man-made and other accidents in Russia, Ukraine, and the Baltic States. There is a problem with waste management. Businesses Belarus pollutes the environment 1.5-2 times more in comparison with industrially developed countries [6].

Serious environmental problems also exist in Armenia, the most severe of which are related to air pollution, habitat protection, and overexploitation of water resources. About $80 \%$ of the land in Armenia is subject to some degree of degradation, and $44 \%$ of the entire territory has a problem of desertification [7]. From the effects of erosion and landslides from agricultural turnover over the past 30 years withdrawn 140 thousand hectares of arable land and 300 thousand hectares of hayfields and pastures; of the 114 thousand hectares of eroded land subject to reclamation, about $3.5 \%$ has been restored. there are prospects for waterlogging and the complete destruction of the unique ecosystem of lake Sevan, where the water level has fallen by 20 meters. The share of territories covered with forests has decreased from $11.2 \%$ to $8-9 \%[8,12-15]$. The air environment is in a critical state: 33.1 
tons of various metals are released into the atmosphere annually, including mainly copper and lead [9]. Negative climate changes are observed.

The difficult environmental situation in Kyrgyzstan. Against the backdrop of global warming and desiccation The Aral Sea is experiencing intensive melting of glaciers, the volume of which has decreased in recent years. 30 years by $25-30 \%$, and the area of - by $40 \%$. Interplastic artesian water reserves decreased by $40 \%$, and in the Republic there is a problem of drinking water [10, 13-14]. Lake Issyk-Kul bears a large anthropogenic load. On the territory of the Republic there are about 1,200 radioactive sources that were actively developed in Soviet times. The problem is acute uranium tailings dumps and toxic industrial waste. So, the total volume of solid radioactive waste located in seismic, mudflow -prone, flood -prone areas, as well as on the banks of rivers, exceeds 130 million $\mathrm{m} 3$ and covers an area of 650 hectares [11, 16-18]. If they are destroyed, there is a risk of radioactive contamination not only for the population Kyrgyzstan, but also for residents of cross-border States: Uzbekistan, Tajikistan, Kazakhstan.

\section{Literature review}

According to the study the center for environmental policy and law at Yale University, which calculates ratings for countries around the world on the environmental performance index (The Environmental Performance Index, (EPI). This index ranks countries by their environmental achievements, and States can use it to compare their achievements and shortcomings with other countries (table 2) [13, 15-17].

Environmental performance index (The environmental Performance Index, EPI) shows the state of sustainable development in the country context. Environmental performance index - this is a combined indicator of the state of environmental protection and the effectiveness of natural resource management, calculated by Center for environmental policy and law at Yale University.

The index measures a country's achievements in terms of the state of ecology and natural resource management based on There are 32 indicators in 11 categories that reflect various aspects of the state of the natural environment and the viability of its ecological systems, conservation of biological diversity, combating climate change, public health, economic practices.

The index methodology has been developed so that States can compare their own successes and shortcomings with other countries. The comparison was made using 16 indicators (76 in the environmental sustainability index) from six policy categories grouped into two comprehensive environmental groups: 1) reducing the environmental burden on human health; 2) ensuring the viability of ecosystems and the rational use of natural resources. EPI evolves with each new report.

Environmental performance index The 2020 global economic Outlook index (EPI) provides a summary of the state of sustainable development around the world. EPI 2020 it occurs in the midst of a crisis COVID-19, which has challenged public health systems around the world and disrupted economic activity in every country. The global pandemic has clearly demonstrated the deep interdependence of all countries and peoples on a global scale. Land, as well as the importance of investing in sustainability. The unintended consequences of the economic downturn in many countries include a sharp drop in pollution levels and the return of wildlife. 


\section{Results}

As a result of the study, we will evaluate the level of air pollution in countries EEU and the impact of their results on environmental safety in the context of sustainable development of the region.

Consider the environmental well-being (EW) of the EAEU countries according to table 1.

Table 1. A Ranking of countries EAEU on Environmental well-being (EW).

\begin{tabular}{|c|c|c|c|c|c|c|}
\hline \multirow{3}{*}{ country } & \multicolumn{6}{|c|}{ Environmental well-being (EW) } \\
\hline & \multicolumn{2}{|c|}{2006} & \multicolumn{2}{|c|}{2016} & \multicolumn{2}{|c|}{2018} \\
\hline & rating & index & rating & index & rating & index \\
\hline Armenia & 68 & 5.2 & 108 & 4.0 & 55 & 6.4 \\
\hline Belarus & 104 & 3.5 & 125 & 3.6 & 35 & 4.9 \\
\hline Kazakhstan & 135 & 2.5 & 138 & 2.7 & 56 & 3.1 \\
\hline Kyrgyzstan & 40 & 6.4 & 77 & 4.9 & 71 & 5.8 \\
\hline Russia & 140 & 2.4 & 144 & 2.5 & 53 & 2.7 \\
\hline
\end{tabular}

Environmental well-being index (EW) for the EAEU countries it showed the following: in 2006, Armenia (5.2) and Kyrgyzstan (6.4) showed a low index of environmental wellbeing; 2016 was lower than the global average index of environmental well-being (4.8) [12-14] with the exception of In 2018, Armenia (6.4), Belarus (4.9), and Kyrgyzstan (5.8) received a low index of environmental well-being. It is noted that moving towards sustainable development is a huge obstacle for States The EAEU is concerned with environmental issues.

Currently there is a rating of countries EAEU by the environmental performance index, which is compiled on the basis of the countries ' EPI calculated according to.

Table 2. The Ranking of countries EAEU by environmental performance index (The Environmental Performance Index, EPI).

\begin{tabular}{|c|c|c|c|c|c|c|}
\hline \multirow{3}{*}{ country } & \multicolumn{6}{|c|}{ The Environmental Performance Index (EPI) } \\
\hline & \multicolumn{2}{|c|}{2008} & \multicolumn{2}{|c|}{2018} & \multicolumn{2}{|c|}{2020} \\
\hline & rating & index & rating & index & rating & index \\
\hline Armenia & 62 & 77.8 & 63 & 62.1 & 53 & 52.3 \\
\hline Belarus & 43 & 80.5 & 44 & 65.0 & 49 & 53.0 \\
\hline Kazakhstan & 107 & 65.0 & 101 & 54.6 & 85 & 44.7 \\
\hline Kyrgyzstan & 94 & 69.6 & 99 & 54.9 & 105 & 39.8 \\
\hline Russia & 28 & 83.9 & 53 & 63.8 & 58 & 50.5 \\
\hline
\end{tabular}

Based on the results of the table 3 it can be seen that within the framework of the EAEU to Russia and Kazakhstan accounts for more than $97 \%$ of emissions of substances that pollute the atmosphere and have the greatest negative impact on the environment; other States have less impact on the environment.

According to the table data 2, it is noted that state environmental performance ratings The EAEU is dozens of times lower than the ratings of the leading States and from 2008 to 2018 they were lowered. Kazakhstan (101) and Kyrgyzstan (99) had the lowest 
ratings on the environmental performance index in 2018. in 2020, Belarus ranks 1st (49th in the world), thanks to its high performance in waste management, air quality, sanitation and drinking water. Russia, the largest country in the region, is ranked 3rd in the region and 58th overall. Kazakhstan (85) and Kyrgyzstan (105) also occupy the lowest ranking. rating. Absolute value of indexes EPI for the EAEU countries from 2008 to 2020, it decreased. This once again demonstrates the unfavorable environmental situation in the countries of the Eurasian economic Union. Economic European Union, which indicates the need for coordinated policy actions in the field of public health and environmental protection.

Table 3. Emissions of air pollutants from stationary sources in the EAEU countries in 20152019 (thousand tons).

\begin{tabular}{|c|c|c|c|c|c|c|}
\hline Country & 2015 & 2016 & 2017 & 2018 & 2019 & $\begin{array}{l}2019 / 201 \\
5 \quad \text { (in \%) }\end{array}$ \\
\hline \multicolumn{7}{|c|}{ Armenia } \\
\hline $\begin{array}{l}\text { Total emissions, } \\
\text { thous. tons }\end{array}$ & 128.9 & 131.8 & 141.3 & 114.0 & 89.7 & 69.59 \\
\hline $\begin{array}{l}\text { Capture and } \\
\text { decontamination, } \\
\text { thousand tons }\end{array}$ & 97.0 & 67.3 & 98.4 & 129.8 & 121.4 & 125.2 \\
\hline \multicolumn{7}{|c|}{ Belarus } \\
\hline $\begin{array}{l}\text { Total emissions, } \\
\text { thous. tons }\end{array}$ & 458.3 & 453.1 & 453.4 & 453.3 & 426.1 & 92.97 \\
\hline $\begin{array}{l}\text { Capture and } \\
\text { decontamination, } \\
\text { thousand tons }\end{array}$ & 3187.1 & 2921.4 & 2619.2 & 2574.1 & 2191.5 & 68.76 \\
\hline \multicolumn{7}{|c|}{ Kazakhstan } \\
\hline $\begin{array}{l}\text { Total emissions, } \\
\text { thous. tons }\end{array}$ & 2180.0 & 2271.6 & 2357.8 & 2446.7 & 2483.1 & 113.9 \\
\hline $\begin{array}{l}\text { Capture and } \\
\text { decontamination, } \\
\text { thousand tons }\end{array}$ & 27949.7 & 27485.8 & 28206.7 & 32372.4 & 33767.8 & 120.8 \\
\hline \multicolumn{7}{|c|}{ Kyrgyzstan } \\
\hline $\begin{array}{l}\text { Total emissions, } \\
\text { thous. tons }\end{array}$ & 61.0 & 52.8 & 49.6 & 56.7 & 50.3 & 82.46 \\
\hline $\begin{array}{l}\text { Capture and } \\
\text { decontamination, } \\
\text { thousand tons }\end{array}$ & 395.9 & 337.5 & 365.9 & 422.5 & 339.3 & 85.7 \\
\hline \multicolumn{7}{|c|}{ Russia } \\
\hline $\begin{array}{l}\text { Total emissions, } \\
\text { thous. tons }\end{array}$ & 17296.0 & 17349.0 & 17477.0 & 17068.0 & 17295.0 & 99.99 \\
\hline $\begin{array}{l}\text { Capture and } \\
\text { decontamination, } \\
\text { thousand tons }\end{array}$ & 52.0 & 49.2 & 50.7 & 46.7 & 54.0 & 103.8 \\
\hline \multicolumn{7}{|c|}{ The EAEU } \\
\hline $\begin{array}{l}\text { Total emissions, } \\
\text { thous. tons }\end{array}$ & 20124.2 & 20258.3 & 20479.1 & 20138.7 & 20344.2 & 101.1 \\
\hline $\begin{array}{l}\text { Capture and } \\
\text { decontamination, } \\
\text { thousand tons }\end{array}$ & 83.6 & 80.0 & 82.0 & 82.2 & 88.3 & 105.6 \\
\hline
\end{tabular}

In the Russian Federation and amount to 17.35 , in Kazakhstan -15.75 tons of CO2EQ.; per unit of GDP - 807 tons and 676 tons of CO2-EQ. per million dollars of GDP, respectively. For comparison, in the EU countries, the average specific greenhouse gas 
emissions are 8.77 tons of CO2-EQ. per capita and 238 tons of CO2-EQ. per 1 million us dollars. GDP. In Armenia and Kyrgyzstan's level of air pollution emissions is significantly lower than that of the Russian Federation and Kazakhstan, but this is no longer evidence of achievements in the field of energy conservation, but of an insufficient level of their implementation. industrial development [15-20].

Table 3 data on emissions of solid, gaseous and liquid pollutants from stationary sources also indicate that there are serious environmental problems in the EAEU countries and they confirm the earlier conclusion that the environmental factor strongly hinders the progress of the EAEU countries on the path of sustainable development.

In 2016, by the Council The Eurasian economic Commission adopted a decision «on the formation of priority Eurasian technology platforms» (ETP), including the platform "technologies for environmental development", which defines a list of major joint environmental projects in the following areas:

- creation of environmentally friendly technologies and production facilities.

- development of technologies for environmentally safe waste management, including elimination of accumulated environmental damage;

- development of technologies and systems for monitoring, assessing and predicting the state of the environment, natural and man-made emergencies, and the consequences of climate change, including innovative tools for instrumental pollution control; - creation of technologies for rational use of natural resources, ensuring environmental safety and new environmental standards of human life.

- development of the environmental services market [15-20].

\section{Discussion}

Proposed Conceptual Framework. By country The Eurasian economic Union needs to harmonize environmental legislation and move towards a unified environmental policy, especially in the area of shared natural resources. It is necessary to increase the effectiveness of environmental cooperation with East Asian countries of cross-border interaction.

Next, we would like to focus on the role of the Republic Kazakhstan as one of the leading EAEU countries in ensuring environmental safety in the region. The SDG are a comprehensive, universal set of goals and indicators until 2030 aimed at improving the quality of life of citizens, socio-economic development and environmental sustainability of States. The SDG consist of 17 goals to be achieved by 2030, along with 169 related targets and 242 indicators.

The SDG are designed to contribute to achieving sustainable development by combining three components: economic, social and environmental. The existence of a close relationship between the three components of sustainable development becomes particularly relevant in modern conditions, when the serious consequences of climate change and the need to preserve limited natural resources and transition to a "green" economy becomes obvious.

Holding of the international exhibition «Astana» in Kazakhstan EXPO-2017» and creation with the assistance of international organizations The center for green technologies and investment projects «energy of the future» on the basis of the exhibition was a bright achievement and a significant contribution Kazakhstan 's contribution to international efforts to implement the SDG [17-20].

Implementation of methodology and indicators for Kazakhstan The SDG provide an opportunity for systematic adaptation of the strategic planning and monitoring system Kazakhstan to international standards, taking into account the consonance of 
program documents Kazakhstan, first of all, the "strategy 2050" and the resulting programs, global development goals.

Leading international experts point out the readiness of Kazakhstan implementation and monitoring requirements SDG, it is important to emphasize the high degree of inclusion of targets SDG, in particular target indicators for direct and final results in national, departmental and sectoral strategic development plans.

In table 4, the following data are systematized: sustainable development goals up to 2030 from the point of view of mechanisms of their implementation and achievement of indicators. So, out of the 17 SDG, there are five goals $(6,7,13,14$ and 15) they are aimed at improving environmental well-being in countries.

Table 4. SDG Kazakhstan's goals aimed at improving environmental well-being in the country.

\begin{tabular}{|c|c|c|c|}
\hline № SDGs & SDG content & $\begin{array}{l}\text { Mechanisms for implementing and } \\
\text { achieving the sdgs }\end{array}$ & $\begin{array}{c}\text { Expected } \\
\text { effect }\end{array}$ \\
\hline Goal 6. & $\begin{array}{l}\text { Clean water and } \\
\text { sanitation }\end{array}$ & $\begin{array}{l}\text { Development and introduction to the } \\
\text { action Environmental management Code } \\
\text { Of The Republic Kazakhstan, etc. }\end{array}$ & \multirow{5}{*}{$\begin{array}{l}\text { Economic } \\
\text { effect, } \\
\text { Social effect, } \\
\text { Environmental } \\
\text { effect }\end{array}$} \\
\hline Goal 7. & $\begin{array}{l}\text { Affordable and } \\
\text { clean energy }\end{array}$ & $\begin{array}{l}\text { Holding of the international exhibition } \\
\text { "Astana" in Kazakhstan EXPO-2017» and } \\
\text { the creation of at the center for green } \\
\text { technologies and investment projects } \\
\text { "energy of the future", etc. }\end{array}$ & \\
\hline Goal 13. & $\begin{array}{l}\text { Combating } \\
\text { climate change }\end{array}$ & $\begin{array}{l}\text { Performs state environmental control over } \\
\text { compliance with environmental } \\
\text { legislation Republic Kazakhstan, in } \\
\text { Development and implementation of } \\
\text { environmental management within the } \\
\text { framework of quality standards, etc. }\end{array}$ & \\
\hline Goal 14. & $\begin{array}{l}\text { Marine } \\
\text { ecosystems }\end{array}$ & $\begin{array}{l}\text { Development process Concept of the new } \\
\text { State program water resources } \\
\text { management Republic of Kazakhstan in } \\
\text { accordance with the Water } \\
\text { Code Republic Kazakhstan. } \\
\text { Activities and important contributions of } \\
\text { research organizations (Institute of } \\
\text { geography and water security, etc.) }\end{array}$ & \\
\hline Goal 15. & Land ecosystem & $\begin{array}{l}\text { In 2019, a specialized Agency was created } \\
\text { - Ministry of ecology, Geology and natural } \\
\text { resources Republic Kazakhstan with } \\
\text { granting it the functions of ot in the field of } \\
\text { use and protection of water resources, } \\
\text { water supply, sanitation, forestry, etc. } \\
\text { Active work and huge contribution of non- } \\
\text { governmental organizations, in } \\
\text { particular: Association of environmental } \\
\text { organizations Of Kazakhstan". }\end{array}$ & \\
\hline
\end{tabular}

Kazakhstan with transfer of functions from Ministries of agriculture Republic Kazakhstan in the field of use and protection of water resources, water supply, sanitation, forestry.

Thus, the quality and quantity of water resources are the main development criteria for any state, which directly affect the health and well-being of citizens of the Republic.

In this regard, the main goal is to Concept is the definition of the main ways problem solving save and rational use water resources country, provision of balance socio-economic 
development and opportunities reproduction water resources level requirements regulatory water quality - "sustainable water consumption". The concept will serve as a message to improve the legislative framework, develop measures for the development of the water sector of the economy and state policy on water resources management and water use.

Based on the above, it is necessary to bring the country's water industry to a new level, which will not only consolidate Kazakhstan's position on cross-border cooperation, but also improve the practice of integrated water resources management.

Achieving the above -mentioned sustainable development goals will directly contribute to the further strengthening and global partnership of countries around the world for their sustainable development.

Successful implementation of the above measures will additionally allow accumulate about $8.8 \mathrm{~km} 3$ of water. It is necessary to gradually reduce the area of crops planted with moisture-loving crops (rice and cotton). Construction of new reservoirs and projects to improve the technical condition of canals will continue. It is impossible to increase the area of irrigated land without introducing water-saving irrigation technologies.

In order to use irrigation water efficiently and economically, it is necessary to carry out mass digitalization on 119 main channels by 2025. Taking into account the dependence on cross-border sources in the southern regions, new irrigated land should primarily be introduced in the water-rich Eastern and Northern regions

\section{Conclusion}

Thus, the States have The EAEU has serious environmental problems that hinder their progress towards sustainable development. This is confirmed by the dynamics of the following indices: social sustainability, environmental efficiency, and the progress index for the sustainable development goals. An important role in improving the environmental efficiency of national economies The Eurasian economic Union should play the role of the project "Eurasian technological platforms", among which the platform "technologies of ecological development" is of great importance. The problem conservation of the environment and life on our Planet - a task that the Eurasian countries can only solve by agreeing on their ecological relations with each other and with other countries of the world.

\section{References}

1. E. Lioubimtseva, Food Security Factors and Trends in Central Asia, Encyclopedia of Food Security and Sustainability, Elsevier 3, 134-141 (2019) https://doi.org/10.1016/B978-0-08-100596-5.21983-5

2. S. Diyar, A. Akparova, A. Toktabayev, M. Tyutunnikova, Green Economy Innovation-based Development of Kazakhstan, Procedia - Social and Behavioral Sciences 140, 695-699, 1877-0428 (2014) https://doi.org/10.1016/j.sbspro.2014.04.497

3. G. Mertai, K. Berdykulova, A. Ismagul et.al., The Emerging Digital Economy: Case of Kazakhstan, Procedia - Social and Behavioral Sciences 109, 1287-1291, 1877-0428 (2014) https://doi.org/10.1016/j.sbspro.2013.12.626

4. J.-X. Li, Y.-N. Chen, Ch.-Ch. Xu, Z. Li, Evaluation and analysis of ecological security in arid areas of Central Asia based on the emergy ecological footprint (EEF) model, Journal of Cleaner Production 235, 664-677, 0959-6526 (2019) https://doi.org/10.1016/j.jclepro.2019.07.005.

5. Ecology.Center for support of Russian-Armenian strategic and public initiatives. URL: http://russia-armenia.info/taxonomy/term/157 
6. A. Khanbabyan, Armenia is threatened by desertification (2015) URL: http://noevkovcheg.ru/mag/2015-16-17/5163.html

7. Kyrgyzstan's environmental problems should become a priority URL: http://www.time.kg/vremya-ne-zhdet/48-problemy-ekologii-kyrgyzstana-dolzhnystat-prioritetnymi.html

8. A. Sodiq, A.A.B. Baloch, S.A. Khan, et.al., Towards modern sustainable cities: Review of sustainability principles and trends, Journal of Cleaner Production 227, $972-$ 1001, 0959-6526 (2019) https://doi.org/10.1016/j.jclepro.2019.04.106

9. R.V. Sreeharsha, S.V. Mohan, Symbiotic integration of bioprocesses to design a selfsustainable life supporting ecosystem in a circular economy framework, Bioresource Technology 326 (2021) https://doi.org/10.1016/j.biortech.2021.124712

10. Statistical Yearbook Of the Eurasian economic Union; the Eurasian economic Commission (Moscow: 2020)

11. Brief information about the implementation Sustainable development goals in Kazakhstan.https://egov.kz/cms/ru/articles/development_goals

12. I.A. Zueva, On the development of methods for analyzing and evaluating the socioeconomic development of regions, Bulletin of Moscow University. S.Y. Witte. Series 1: Economics and Management 4(23), 27-36 (2018)

13. L.G. Rudenko, Assessment of the possibility of sustainable environmental, social and economic development of Russia, Bull. of Moscow Univ. S.Yu. Witte. Series 1: Econ. and Manag. 1(20), 20-27 (2017) DOI: 10.21777 / 2307-6135-2017-1-20-27

14. D.N. Baranov, Improving the methodology for calculating labor standards for workers involved in the sanitary maintenance of administrative, public buildings and the adjacent territory, Bulletin of Moscow University. S.Yu. Witte. Series 1: Economics and Management 4(23), 75-81(2017) doi: 10.21777 / 2587-9472-2017-4-75-81

15. T.A. Burtseva, I.A. Zueva, Directions of improving methods for monitoring the implementation of regional development strategies in the digital information environment, Bulletin of Moscow University. S.Yu. Witte. Series 1: Economics and Management 4(27), 43-50 (2018) doi: 10.21777 / 2587-554X-2018-4-43-50

16. A. Zhansagimova, Development of rural tourism after the coronavirus pandemic, Journal of Environmental Management and Tourism 11(8), 2020-2027 (2020)

17. E.V. Ribokene, Evaluation of the forms and principles of state regulation of the tourist sphere, Bulletin of Moscow University. S.Y. Witte. Series 1: Economics and Management 4(23), 82-90 (2017) doi: 10.21777 / 2587-9472-2017-4-82-90

18. E.V. Ribokene, Assessment of the current state of small and medium-sized enterprises in the software development industry, Bull of Moscow University. S.Yu. Witte. Series 1: Econ. and Manag. 1(24), 71-80 (2018) doi: 10.21777 / 2587-9472-2018-1-71-80

19. O. Semenyuk, T. Abdrashitova, E. Beloussova, et.al., The influence of ecology and economic factors on eco-architecture and the design of energy efficient buildings, World Transactions on Engineering and Technology Education 16, 2, 186- 192 (2018)

20. T.S. Sobol, Modern level and quality of life of the population of Russia, Bulletin of Moscow University S.Y. Witte. Series 1: Economics and Management 2 (25), 7-14 (2018) DOI: $10.21777 / 2587-554 \mathrm{X}-2018-2-7-14$ 